\title{
FACTORS AFFECTING PAYMENT OF INCOME TAXES BY ARTISANAL FIRMS IN KUMASI.
}

\author{
SAMUEL OPPONG BOAMPONG
}

\begin{abstract}
Payment of Income taxes has been extensively studied in Ghana since 1960. It has been analysed and evaluated by academicians, professionals, and governments. The hardest thing in the world to understand is income tax. Nevertheless it is vital that income tax is understood as it forms a critical element of how a government affects the lives of its citizens. The primary objective for this study was to find out factors affecting artisanal firms in the payment of income taxes. The other objectives were to identify peculiar challenges faced by Garage Owners, Kumasi, towards income tax payment. To identify ways of bridging challenges faced by both Ghana Revenue Authority (Domestic Division) and the informal sector taxpayer to inculcate culture of tax compliance. The research design employed in the study was purely qualitative, descriptive, exploratory and quantitative. The major research instrument used was structured questionnaire and interviews. The data gathered were analysed with the use of excel and SPSS. The study identifies the difficulties faced by the GRA in taxing the artisanal firm owners. It was recommended that the Ghana Revenue Authority, Domestic Division (GRA) should adopt intensive education and training for artisanal firm owners. GRA should provide personnel assistance for the artisanal firm owners in their preparation and submission of returns and provision of logistics to enable GRA to provide efficient and effective services to the various taxpayers.
\end{abstract}

\section{INTRODUCTION}

Many developing countries including Ghana are faced with the problems of raising the necessary revenues to meet governments' expenditure. Governments' budgeted revenues usually fall short of the expected expenditure.

Albert Einstein (as cited in Slemrod and Bakija, 1996), once said that the hardest thing in the world to understand is income tax.
Nevertheless, it is vital that income tax is understood as it forms a critical element of how a government affects the lives of its citizens.

Lamont (1992) states, that of all the powers of government, none bears so incisively upon the welfare of citizens, both privately and in their economic enterprise, as does its power to tax. The effect of taxation is that subjects are forced to give up hard earned earnings or possessions, or in the early days, also payments in kind, without receiving visible benefits in return (Coetzee 1993: Thereon, 1994)

Citizens expect government to provide goods and services, and these government expenditures require the generation of revenues. Some of the social services include the provision of National Health Insurance Scheme (NHIS), Free Health Care for Pregnant Women, Capitation Grants for government basic schools, School Feeding Programme, Mass Cocoa Spraying Exercise, Free School Uniform Project, Ghana Youth Employment and Entrepreneur Development Agency (GYEEDA) and Savannah Accelerated Development Authority (SADA). Some economic infrastructure development include increase in energy supplies, such as building of Aboadze Thermal Plant, Osagyefo Badge, construction of Bui Dam, expansions of urban roads networks such as Sofoline interchange and road from Sofoline to Abuakwa to ease traffic congestion in that route and also other feeder roads to link rural communities to urban centres. These have resulted in ever increasing expenditure of economies.

Over the past two decades (20years), the government of Ghana has consistently spent more than it is able to generate as revenue and the gap is often financed with foreign aid, which has perpetuated the country's aid dependency (Osei and Quartey 2005). Ghana's budget deficit for 2012 fiscal year was GHC $8,648,700.00$ Ghana Cedis, which represents $12 \%$ of Gross Domestic Product (GDP) against the target. 
To avoid excessive foreign financing, which may, in the long run, lead to problems of debt sustainability, developing countries need to rely substantially on domestic revenue mobilization (Gupta, 2003).

In the past, government expenditure was mainly financed by foreign exchange earnings. The unfavourable shifts in the terms of trade due to drastic fall in foreign earnings have necessitated an urgent need for the mobilisation of funds locally. Also, due to non-performance of state enterprises and the introduction of private sector management practices, almost all state enterprises that hitherto were generating some income for the state have been divested.

The government has shown an increasing desire to tax the informal sector, and has introduced several taxes to specifically target informal sector operators. These include the Vehicle Income Tax on public transport operators, the Tax Stamp for collecting income tax from small traders, and the Flat Rate Scheme for expanding the reach of Value Added Tax (VAT). In the informal sector if they can, because the perceived benefits outweigh the perceived costs. Enterprises in developing countries in particular rarely see their tax contribution at work in the form of government services.

\section{PECULIAR CHALLENGES FACED BY} INFORMAL SECTOR TAX PAYERS

\section{Cash Transactions}

\section{Lack of Proper Record and Book Keeping}

\section{Frequent Changes in Tax Laws}

\section{Scope of Informal Sector and Taxation}

\section{DATA ANALYSIS}

A sample size of 353 garage owners and 2 GRA officials were selected. A probability sampling approach was employed in the study. It was realised that informal sector taxpayers at Suame Magazine and Sofoline have associations. Each tax payer belongs to an association. Some even belong to more than one association.

Table 1: Number of Respondents Surveyed in each Population Group. (The Association Groups)

\section{Associations (population group)}

1 General Garages Association

2 Suame Magazine Industrial (SMIDO)

3 Mechanical Association

4 Condemned Sellers Association

5 Association of Foundry Men

6 Ghana Revenue Authority, Domestic Division Totals

Source: Author's field survey (2014

\author{
1. Age distribution \\ 3. Gender composition \\ 5. Educational backgrounds
}
2. Working Life
4. Population groups
6. Working Status

Number of respondents surveyed

113

85

70

0


Proc. of the Third Intl. Conf. on Advances in Economics, Management and Social Study - EMS 2015

Copyright $(\odot$ Institute of Research Engineers and Doctors, USA .All rights reserved.

ISBN: 978-1-63248-058-3 doi: 10.15224/ 978-1-63248-058-3-94

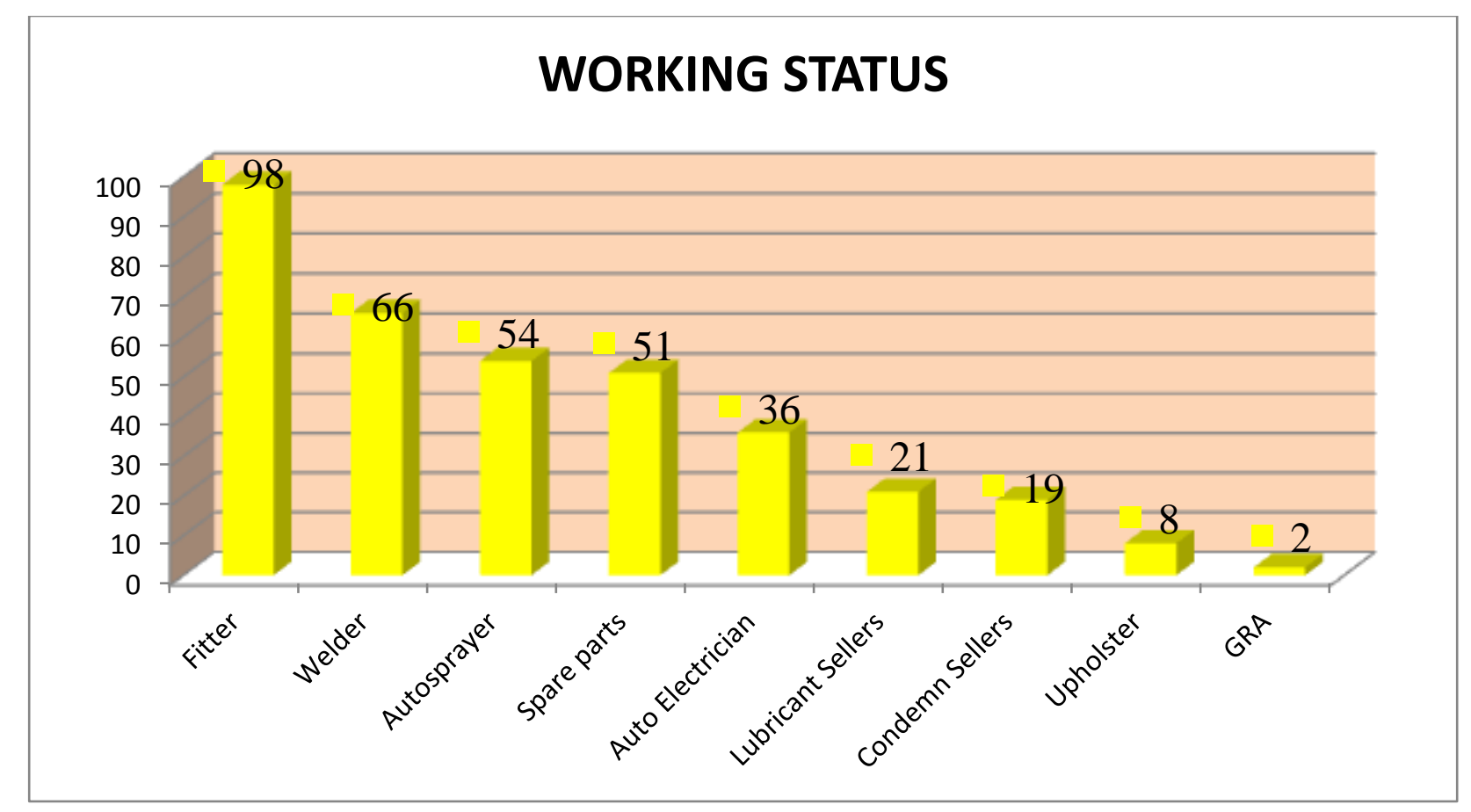

Income of Respondents

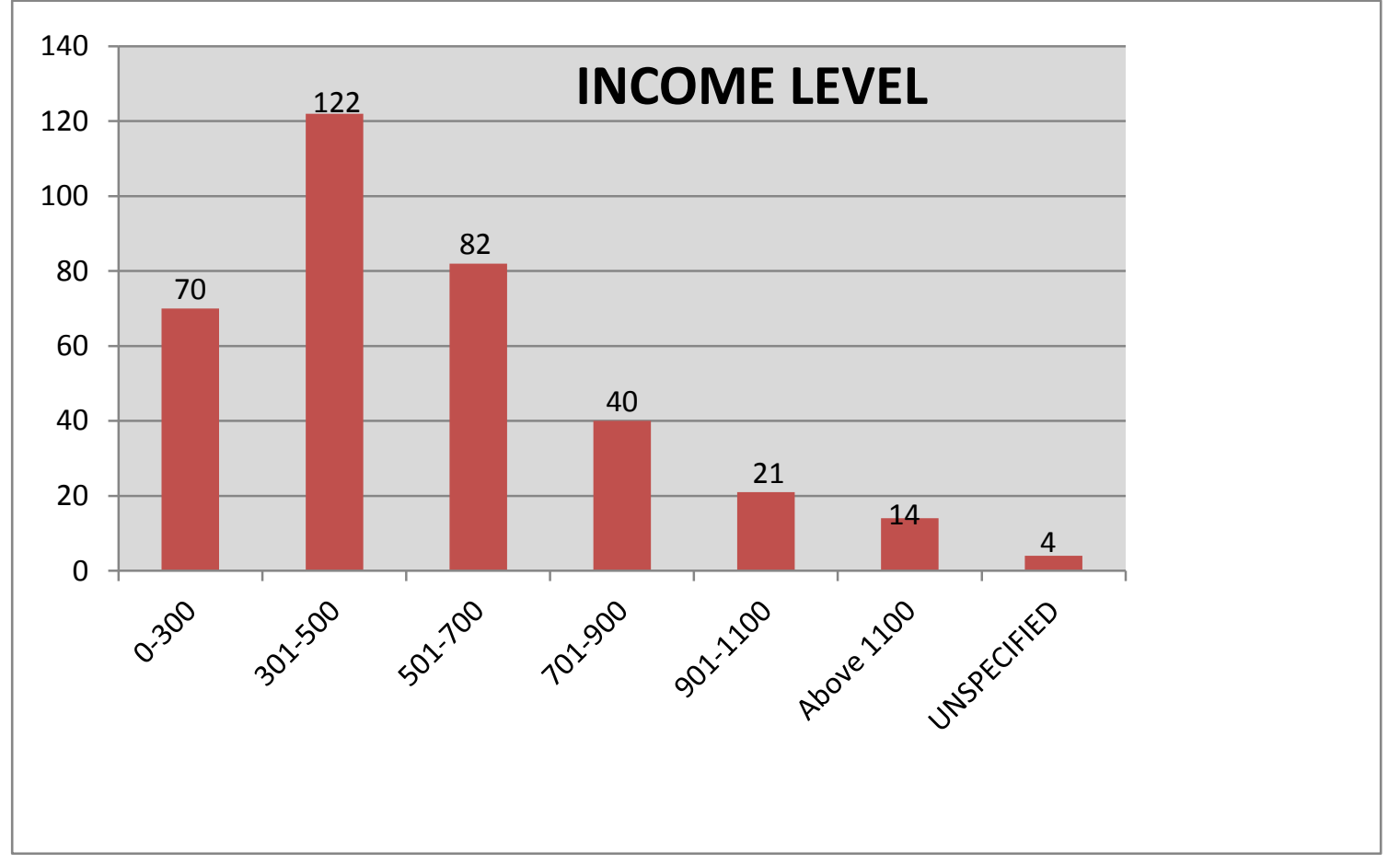




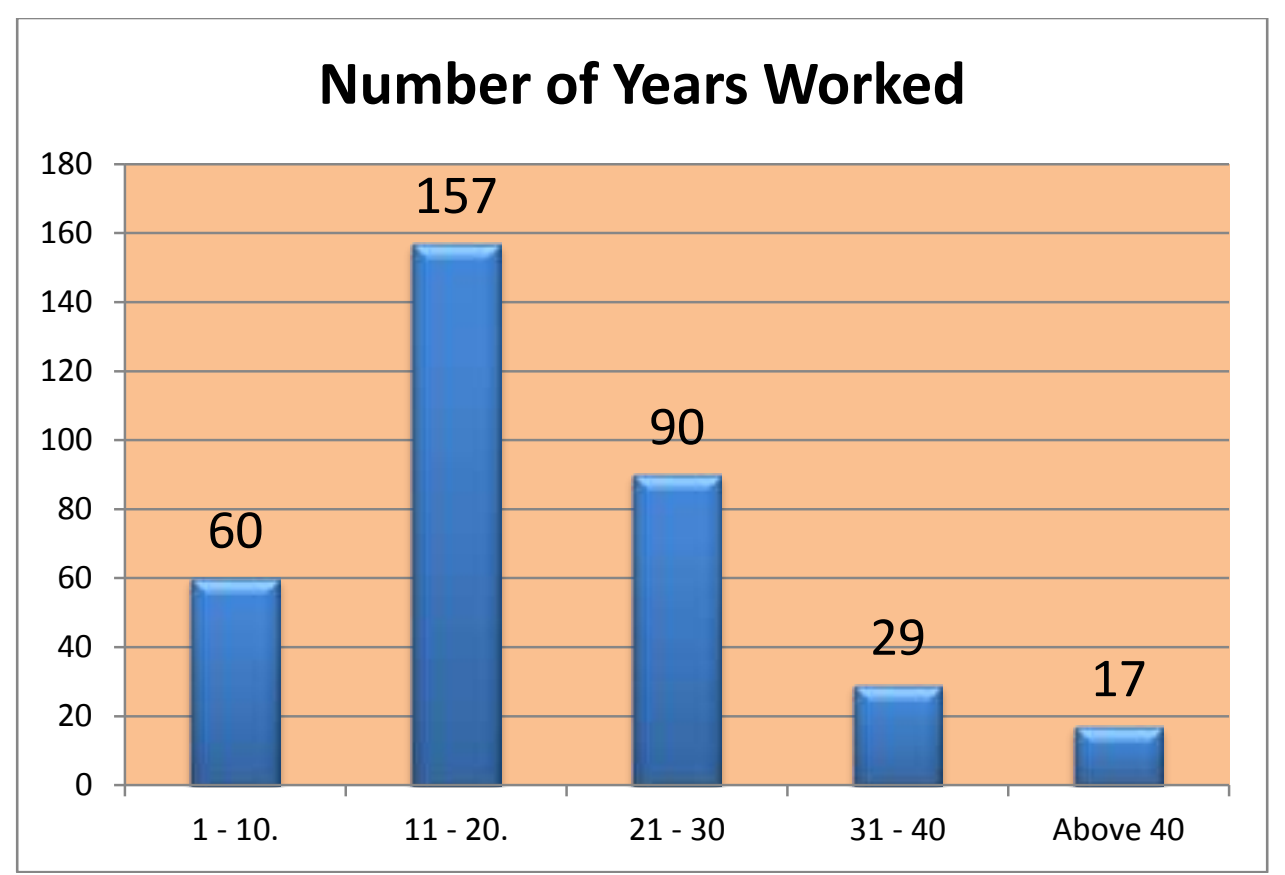

Number of Years Worked

Source: Author's field survey (2014)

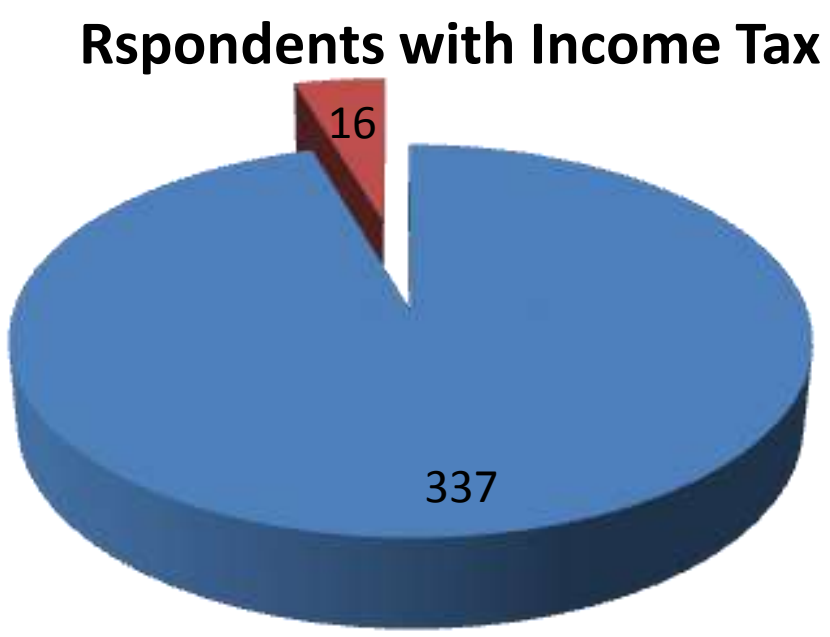

Respondents with Income Tax File with GRA

Source: Author's field survey (2014) 
Proc. of the Third Intl. Conf. on Advances in Economics, Management and Social Study - EMS 2015

Copyright (C) Institute of Research Engineers and Doctors, USA .All rights reserved.

ISBN: 978-1-63248-058-3 doi: 10.15224/ 978-1-63248-058-3-94

\section{Challenges Faced by Informal Sector (Garage Owners at Suame Magazine) Towards Income Tax Payment. \\ Table 2: Attitudes of Respondents towards General Tax-Related Statements}

\begin{tabular}{|c|c|c|c|c|c|c|}
\hline \multirow[t]{2}{*}{ Statement Relating to General Tax Issue } & \multicolumn{2}{|c|}{ Agree } & \multicolumn{2}{|c|}{ Disagree } & \multicolumn{2}{|c|}{ Neutral } \\
\hline & Freq & $\%$ & Freq & $\%$ & Freq & $\%$ \\
\hline $\begin{array}{l}1 \text { A large proportion of taxes is used by the } \\
\text { government for meaningless purposes }\end{array}$ & 214 & 60.6 & 115 & 32.6 & 24 & 6.8 \\
\hline 2 Income tax slows down their path to success & 290 & 82.5 & 40 & 11 & 23 & 6.5 \\
\hline 3 Income tax rate must be reduced & 274 & 77.6 & 51 & 14.4 & 28 & 8 \\
\hline 4 Waste and corruption in government is high & 280 & 79.3 & 54 & 15.3 & 19 & 5.4 \\
\hline $\begin{array}{l}5 \text { The amount of tax I have to pay is reasonable } \\
\text { considering the benefits received }\end{array}$ & 199 & 56.4 & 132 & 37.4 & 22 & 6.2 \\
\hline $\begin{array}{l}6 \text { The government does not provide enough } \\
\text { information about how they use taxpayers' money }\end{array}$ & 154 & 43.6 & 114 & 32.3 & 85 & 24.1 \\
\hline $\begin{array}{l}7 \text { It is unfair to pay tax considering revenue from } \\
\text { gold, cocoa, diamonds, timber, grants etc }\end{array}$ & 112 & 31.7 & 206 & 58.3 & 35 & 10 \\
\hline 8 I do not know why I have to pay income tax & 110 & 31.2 & 200 & 56.7 & 43 & 12.1 \\
\hline 9 Wealthy people should pay income tax & 223 & 63.2 & 100 & 28.3 & 30 & 8.5 \\
\hline
\end{tabular}

\section{Recommendations}

On the basis of the findings of the study, the researcher wishes to offer the following recommendations.

\section{Provision of Logistic}

\section{Regular Tax Education for Taxpayers}

\section{Provision of Book Keeping Assistance}

4. Effective Enforcement of Tax Regulations 5. Regular Task Forcing by GRA

\section{Conclusion}

The study has shown that GRA has been making efforts to improve upon the factors affecting the payment of taxes by the informal sector. In response to these factors of standard system of taxation, reforms have been made to introduce presumptive tax regimes on informal sector operators which include garage owners at Suame Magazine and Sofoline, Kumasi. However, the fact remains that in spite of these efforts the results achieved remain somewhat poor, as challenges in the presumptive tax regimes have not well been addressed.

\section{REFERENCES}

Ablorh-Quarcoo, D. S. (2006). The Re-launch of the Tax Stamp. Speech delivered by the Commissioner of Internal Revenue Revenue Service. Accra: Intemal Revermue Service.

Adam, S. (1776). An Inquiry into the Nature and Causes of the Wealth of Nations. New York, United States of America: P. F. Collier and Son company.

Adjei-Djan. (2005). The informal sector Asource of Enhanced Nation Revenue Mobilisation. Sanaa Lodge Hotel. Cape Coast: Intemal Revenue Service Management Seminar.

Agyemang, E. D. (1982). Priciple of Ghana Taxation. Accra.

Ayee, J. (2007). Building Tax Compliance through Reciprocity with Govemment. Paper Presented at the Foreign Investment advisory Service. Alisa Hotel, Accra. 